\title{
Multiple infestation of Apis mellifera L. brood cells and reproduction in Varroa jacobsoni Oud
}

\author{
S. Fuchs and K. Langenbach
}

Institut für Bienenkunde (Polytechnische Gesellschaft), FB Biologie der J.W. Goethe-Universität, Frankfurt am Main, Karl-von-Frisch-Weg 2, 6370 Oberursel, FRG

(received 6 June 1988, accepted 30 March 1989)

Summary - Infestation by adult Varroa mites and offspring numbers were recorded in worker brood cells (day 14-20) and drone brood cells (day 17-23). The numbers of offspring likely to develop to adulthood were calculated according to a scheme based on the developmental stage of each pupa and the time interval to uncapping of the brood cells. With increasing numbers of Varroa infesting a cell, the numbers of female offspring per Varroa decreased within both cell types. Apparently, this decrease was based on fewer offspring produced per Varroa rather than by complete nonreproduction of some mites. Reproduction within combs, calculated according to the mite distributions, was even lower. This density-dependent reproduction is likely to influence population growth considerably. With increasing cell infestation, the proportion of males increased, thus reducing the bias of the sex ratio towards females.

Apls mellifera - Varroa jacobsoni - population dynamics - reproduction - Infestation rate

Résumé - Infestation multiple et reproduction de Varroa jacobsoni Oud. dans les cellules de couvain d'Apls mellifica. On a étudié le rapport entre le nombre d'acariens Varroa qui infestent une cellule de couvain et leur taux de reproduction. On a dénombré 1062 acariens adultes et 2909 formes immatures dans 588 cellules d'ouvrières et 2596 adultes et 6155 formes immatures dans 906 cellules de mâles.

N'ont survécu que les descendants qui pouvaient achever leur cycle de développement dans le laps de temps restant jusqu'à l'éclosion de l'abeille. Pour tous les stades trouvés, on doit déterminer la probabilité de développement complet, d'après le temps encore nécessaire pour achever le développement de l'acarien, et l'âge de l'abeille (Jay, 1962 et série de photos personnelles) (Tableau I). Tous les stades de développement situés au-dessus des diagonales peuvent atteindre le stade adulte, ceux situés au-dessous ne le peuvent pas. Puisqu'on ne peut déterminer l'áge de l'acarien pendant un stade immature donné, on n'obtient que des probabilités.

On a évalué la reproduction normale de Varroa d'après les cellules infestées par un seul acarien. On a fait des sous-groupes afin d'améliorer la comparaison (Tableau II). Dans les cellules de mâles on a obtenu 2,21 descendants femelles et 0,61 descendants mâles, dans les cellules d'ouvrières respectivement 1,4 et 0,63. Lorsque l'infestation des cellules augmente, le nombre de descendants de Varroa diminue nettement (Fig. 1). Dans les cellules d'ouvrières la reproduction par acarien est inférieure à un descendant femelle par cycle reproducteur, à partir de 4 varroa dans les cellules d'ouvrières et de 8 varroa dans celles de mâles.

La diminution de la reproduction, parallèlement à l'augmentation de l'infestation n'est pas due au fait que certains acariens ne se reproduisent pas du tout. Si tel était le cas, il faudrait s'attendre à 
ce que le sex ratio de la descendance reste constant, comme dans les cellules infestées par un seul acarien (cellules d'ouvrières $1: 2,22$ et cellules de mâles $1: 3,62$ ). Les résultats montrent que dans la séquence de descendance (femelle, mâle, femelle, femelle, etc.) les descendants les plus éloignés manquent, ce qui conduit, particulièrement dans les cellules d'abeilles mâles, à une forte augmentation de la proportion relative d'acariens mâles (Tableau III).

Au niveau des rayons de couvain, les calculs montrent qu'il y a un affaiblissement de la reproduction moyenne pour chaque infestation moyenne de cellule, calculée par rapport à la reproduction dans les cellules prises individuellement, dans les cellules de mâles, que ce soit dans celles d'ouvrières (Fig. 2). Les effets de la reproduction, fonction de la densité, sur la croissance de la population sont importants dans les cellules d'ouvrières, et encore plus dans celles de mâles (Fig. 3). Dans la pratique, il faut retenir que de petites quantités de cellules de mâles sont très vite surpeuplées et ne peuvent plus, ou de façon insignifiante, contribuer à la croissance de la population d'acariens.

Le déplacement du sex ratio vers une plus grande proportion de mâles est intéressante, car il correspond au résultat prévu par la théorie. Lors de l'accouplement entre frère et sceur à l'intérieur d'une cellule operculée, la production d'un mâle seulement suffit, tandis que le nombre de mâles devrait égaler celui du sex ratio lorsque la compétition s'accroit.

\section{Apls mellifica - Varroa jacobsoni — dynamique des populations — reproduction — infestation}

Zusammenfassung - Mehrfachbefall und Reproduktion von Varroa jacobsoni Oud. In Brutzellen von A. mellffera L. Der Zusammenhang zwischen der Anzahl von VarroaMilben, die eine Brutzelle befallen, und deren Reproduktion wurde untersucht. In 588 Arbeiterinnenzellen wurden insgesamt 1062 Milben mit 2909 lebenden Nachkommensstadien, in 906 Drohnenzellen 2596 Varroa milben mit 6155 Nachkommensstadien ausgewertet.

Nur diejenigen Nachkommen überleben, die ihre Entwicklung innerhalb der verbleibenden Zeit bis zum Schlupf der Bienen abschliessen können. Für alle gefundenen Stadien muss anhand der noch zur vollständigen Entwicklung benötigten Zeit (Ifantidis, 1983) und des Entwicklungsalters der Bienen (Jay, 1962 und eigene Photoserie) die Chance zur Ausentwicklung beurteilt werden. Hierzu wurde ein Schema entwickelt (Tabelle l). Alle Entwicklungsstadien oberhalb der Diagonalen können sich ausentwickeln, alle unterhalb nicht. Da das Milbenalter innerhalb eines Larvenstadiums nicht feststellbar ist, wurden Wahrscheinlichkeiten ermittelt.

Die normale Reproduktion von Varroa ergibt sich aus der Untersuchung einfach befallener Zellen. Hierbei wurden zur besseren Vergleichbarkeit Untergruppen getrennt aufgeführt (Tabelle II). In Drohnenzellen ergaben sich insgesamt 2,21 weibliche und 0,61 männliche, in Arbeiterinnenzellen 1,4 weibliche und 0,63 männliche sich ausentwickelnde Nachkommen.

Mit steigendem Befall der Zellen nimmt die Anzahl von Nachkommen pro Varroa deutlich ab (Abb. 1). In Arbeiterinnenzellen werden etwa ab 4 Varroae, in Drohnenzellen etwa ab 8 Varroae weniger als ein weiblicher Nachkomme pro Zellendurchgang erzeugt.

Die Verringerung der Reproduktion mit steigendem Zellenbefall beruht nicht darauf, dass einzelne Milben ganz auf Reproduktion verzichten. In diesem Falle wäre zu erwarten, daB das Geschlechterverhältnis der Nachkommen konstant so bleibt, wie in einfach befallenen Zellen (Arbeiterinnenzellen $1: 2,22$, Drohnenzellen $1: 3,62$ ). Die Ergebnisse deuten eher darauf hin, dass in der Sequenz der Nachkommen (weiblich, männlich, weiblich, weiblich...) die späteren Nachkommen ausfallen, was insbesondere in den Drohnenzellen zu einer deutlichen Anhebung des relativen Anteils an Männchen führt (Tabelle III).

Aus der Vermehrung in den einzelnen Zellen kann unter Berücksichtigung der Verteilung von Milben auf die Waben für das Betallsmittel die Reproduktion errechnet werden (Abb. 2). Diese liegt in beiden Zelltypen niedriger als in Zellen des Befallsmittels. Die Reproduktionsrate wird hierdurch zusătzlich vermindert.

Die Auswirkungen der Dichteabhängigkeit der Reproduktion auf das Populationswachstum sind in Arbeiterinnenzellen und insbesondere in Drohnenzellen erheblich (Abb. 3). In der Praxis dürfte vor allem von Bedeutung sein, dass kleine Drohnenzellenmengen sehr rasch überfült werden und dann nicht mehr oder nur unwesentlich zum weiteren Wachstum der Milbenpopulationen beitragen.

Die Verschiebung des Geschlechterverhältnisses in Richtung eines höheren Anteils an Männchen ist zusätzlich von Interesse, da sie der theoretischen Erwartung entspricht. Bei Geschwisterpaarung innerhalb der abgeschlossenen Zellen ist die Produktion von nur einem 
Männchen ausreichend, während sich mit zunehmender Konkurrenz das Geschlechterverhältnis angleichen sollte (Fisher, 1930; Hamilton, 1967).

Apls mellifera - Varroa jacobsoni — Populationsdynamik - Reproduktion - Zellenbefall

\section{Introduction}

Varroa mites enter honeybee brood cells for reproduction. The number of viable female offspring they produce during one cell passage is a key value for population increase within colonies ( 1.3 within worker cells and 2.6 within drone cells, Schultz, 1984). An investigation of drone cells by Hänel (1985) indicated that reproduction is lowered if higher numbers of Varroa reproduce in one cell. In this study, this relationship is studied in more detail for both worker and drone brood cells.

A density-dependent component in the reproduction of Varroa might slow down population growth at high population levels. This applies especially to drone cells, which are preferred by the mites and are usually present in small numbers. The determination of factors inducing lower reproduction might lead to new control methods.

The pattern of Varroa reproduction has to be reconstructed by opening numerous brood cells and examining their contents. By this method, Ifantidis (1983) determined the times of oviposition and the duration of the developmental stages. When the bee brood hatches, adult female Varroa offspring cannot be distinguished from parental females. To reliably determine reproduction rates, cells have to be opened when parents can still be identified. Our aim was to develop a schedule to estimate viable offspring numbers from the larval stage of the mites based on developmental times according to Ifantidis (1983) and from the age of the pupae.

\section{Materials and Methods}

During the bee season (May to August 1987), combs with sealed brood cells (d 14-20 of development in worker brood and d 17-23 in drone brood) were taken from highly infested colonies of Apis mellifera carnica and were frozen. Younger combs were kept within an incubator until they reached the respective ages. Cells were inspected individually with a dissecting scope. The age of the pupa was scored according to Jay (1962) and to a series of color photographs taken from pupae of known age.

Varroa were identified as adults or offspring. The offspring were differentiated into 6 developmental stages (egg-larva, protonympha mobile, protonympha immobile, deutonympha mobile, deutonympha immobile, imago). Sex was determined from the deutonymphal stage onwards.

The impact of the dependency of reproduction from cell infestation on the reproduction within brood combs and on population growth was assessed using computer models described in more detail by Fuchs (1985; 1989). Basically, for each average infestation rate (Varroa/cell), the proportions of cells containing $0,1,2,3$, etc. mites was calculated by the superimposition of 10 Poisson distributions, which matches closely the observed distributions. The contribution of each of these cell proportions to the reproduction within the combs was then calculated according to the experimental data. In addition, it was assumed that worker cells containing more than 7 and drone cells containing more than 16 Varroa will not develop. The simultaneous contributions of worker cells and drone cells was calculated according to their proportions and assuming an 8-fold preference of the mites for drone cells (Schulz, 1984; Fuchs, submitted).

The impact on population growth was demonstrated over a period of 12 generations by assuming a simplified pattern of reproduction, in which Varroa reproduces during one cell passage only and dies 
thereafter. The reproduction was assumed to be that calculated for brood combs. No other factors were included.

\section{Results}

\section{Preparation of cells}

Within 588 infested worker brood cells from 11 brood combs, 1062 adult mites and 2909 live offspring were found. 906 drone cells from 32 brood combs contained 2596 adult mites with 6155 live offspring. The distribution of the developmental stages in relation to the age of the pupa or, more importantly, to the time until uncapping is given in Table I. In eggs and protonympha, males and females are scored together, while they are given separately for the older stages.

\section{Surviving to adulthood probabilities}

In Table 1, developmental periods of Varroa are represented on the horizontal axis and the stage of development of the bee pupae in a downward direction. The drawn-in diagonals thus give, on the assumption that after its last molt Varroa needs another $24 \mathrm{~h}$ for hardening and mating, a separation line between stages which will reach adulthood (above the diagonal) and stages that will not (below the diagonal). While the developmental stages of Varroa are fairly distinct, the age within a stage is difficult to assess. Without knowing this, the probability of reaching adulthood is represented, at any age of the pupa, by the proportion of the stage duration above the diagonal. Calculated from this, the survival change of any developmental stage of female Varroa offspring is given for each day of pupa development. Using these values, the offspring completing their development was evaluated for each cell.

\section{Cells infested by one Varroa}

As in cases of multiple cell infestation, offspring cannot be attributed to a single parent, the standard reproduction of Varroa can best be evaluated from cells infested by only one Varroa.

Four groups of cells were considered separately (Table II). In the main group, immature male and female offspring were present. Some cells contained only female offspring, some only male offspring, some no offspring at all, and some could not specifically be attributed to either of these groups, since they contained only eggs and protonympha.

Since proportions of these groups may vary between studies, the relative contributions to reproduction were calculated separately for each cell according to the above scheme. In these calculations, all eggs and protonympha were considered female. This might introduce an error. However, the main portion of males were produced earlier due to the normal reproductive pattern, by which only the second-laid egg develops into a male. Thus, male protonympha are rare later than the 6 th day before hatching (cf. Table I).

\section{Cells infested by more than one Varroa}

With more than one Varroa per cell, increasing numbers of cells contain both male and female offspring and other subgroups get increasingly rare. Numbers of offspring reaching maturity were calculated as above, but without considering subgroups separately (Table III). 


\begin{tabular}{|c|c|c|c|c|c|c|c|}
\hline \multirow{3}{*}{ : } & $a^{-1} 0$ & $\stackrel{i}{-1}^{-1}$ & $\vec{n}_{0}^{-1} a$ & $a^{-1} \overrightarrow{0}$ & $\infty^{-1}:$ & $\stackrel{n}{n}^{-1} \dot{m}$ & nin ó \\
\hline & in 0 & 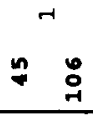 & $\begin{array}{r}r \\
m \quad \stackrel{a}{f} \\
\end{array}$ & $\begin{array}{l}-1 \\
\bullet \quad \text { ஸ }\end{array}$ & & & $\begin{array}{ll} & 0 \\
0 & 0\end{array}$ \\
\hline & $\begin{array}{l}r \\
\infty \quad \stackrel{\infty}{\sim}\end{array}$ & $\begin{array}{c}r \\
\stackrel{n}{\infty} \quad \stackrel{a}{m}\end{array}$ & 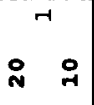 & & $\begin{array}{ll}-1 & 0\end{array}$ & $\begin{array}{l}0 \\
0 \quad m\end{array}$ & $\begin{array}{l}0 \\
0 \\
0\end{array}$ \\
\hline
\end{tabular}

: $\quad$ 들

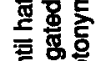

至密응

롫ㄴ.

틍흐요

害要

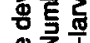

号安

율

훈

흥푱.

8 뜽

\begin{tabular}{|c|c|c|c|c|c|c|c|}
\hline \multirow{3}{*}{ 룰 } & $n^{n-1}$ & $\stackrel{m}{a}^{-1} 0$ & $\stackrel{\bullet}{a}^{-1} a$ & $=$ & $a^{-1}=$ & $:^{-1} \approx$ & -inó \\
\hline & $\underset{F}{F} 0$ & 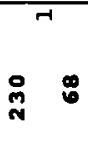 & 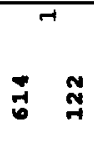 & : & & $\mathbf{N}$ & 00 \\
\hline & $\boldsymbol{n}^{-1} \underset{-}{-1}$ & $\stackrel{-1}{\bullet} \stackrel{0}{\oplus}$ & $\begin{array}{c}n \\
m \\
m \\
m\end{array}$ & $\therefore$ & $\stackrel{0}{\sim}$ & ${ }^{0} \quad N$ & $0^{0} N$ \\
\hline \multirow{3}{*}{$\begin{array}{l}7 \\
+8 \\
+4\end{array}$} & & & Nิตn & $\approx^{\circ} \%$ & $n^{\circ} \mathrm{a}$ & A A & $0^{\circ} 0$ \\
\hline & & & $\sigma i$ & N & $\infty \quad m$ & $\begin{array}{c}0 \\
\text { N }\end{array}$ & $\begin{array}{l}0 \\
0 \quad 0\end{array}$ \\
\hline & $\begin{array}{c}0 \\
i \quad m\end{array}$ & $\begin{array}{c}0 \\
5 \quad m\end{array}$ & $\begin{array}{c}0 \\
0 \\
\stackrel{7}{7}=\end{array}$ & i $=$ & \begin{tabular}{l}
\multicolumn{1}{c}{} \\
$\circ \stackrel{2}{\circ}$
\end{tabular} & $\begin{array}{l}0 \\
0 \quad n\end{array}$ & $\begin{array}{r}0 \\
+\quad 0\end{array}$ \\
\hline
\end{tabular}

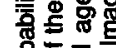

: $\quad$ 웅흐는

-

害要 漹

ญ密吉

n

ज

क्ष

$\div \quad 8$ 형

-

m

要. 드..

웡을

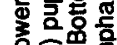

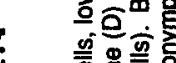

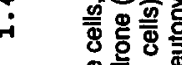

훟

흫호인

- हुँ

(2)

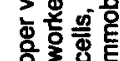

论

ฮิ न

电罗要

Б "

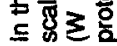


Table II. Calculation of mature offspring of one Varroa infesting a cell.

\begin{tabular}{|c|c|c|c|c|c|c|}
\hline \multirow{3}{*}{$\begin{array}{l}\text { Composition } \\
\text { immature } \\
\text { offspring }\end{array}$} & \multicolumn{3}{|c|}{ Worker cells } & \multicolumn{3}{|c|}{ Drone cells } \\
\hline & \multirow{2}{*}{$\begin{array}{l}c e l / s \\
N\end{array}$} & \multicolumn{2}{|c|}{ offspring } & \multirow[t]{2}{*}{ cells } & \multicolumn{2}{|c|}{ offspring } \\
\hline & & female & male & & female & male \\
\hline $\begin{array}{l}\text { Male }+ \\
\text { female }\end{array}$ & 226 & 1.69 & 0.85 & 176 & 2.76 & 0.94 \\
\hline $\begin{array}{l}\text { Female } \\
\text { only }\end{array}$ & 29 & 0.63 & - & 35 & 1.55 & - \\
\hline $\begin{array}{l}\text { Male } \\
\text { only }\end{array}$ & 8 & - & 0.63 & 3 & - & 1.33 \\
\hline Without & 23 & - & - & 22 & - & - \\
\hline $\begin{array}{l}\text { Protonympha } \\
\text { only }\end{array}$ & 30 & 1.43 & - & 43 & 1.77 & - \\
\hline Total : & 316 & 1.40 & 0.63 & 279 & 2.21 & 0.61 \\
\hline
\end{tabular}

Table III. Maturing offspring per Varroa produced in one cell passage.

\begin{tabular}{|c|c|c|c|c|c|c|c|c|}
\hline \multirow{3}{*}{$\begin{array}{l}\text { Varroa } \\
\text { per } \\
\text { cell }\end{array}$} & \multicolumn{3}{|c|}{ Worker cells } & \multirow[b]{3}{*}{$\begin{array}{l}\text { Sex } \\
\text { ratio } \\
\% \text { male }\end{array}$} & \multicolumn{3}{|c|}{ Drone cells } & \multirow[b]{3}{*}{$\begin{array}{l}\text { Sex } \\
\text { ratio } \\
\% \text { male }\end{array}$} \\
\hline & \multirow{2}{*}{$\begin{array}{l}\text { Number } \\
\text { of } \\
\text { cells }\end{array}$} & \multicolumn{2}{|c|}{$\begin{array}{l}\text { Offspring per } \\
\text { cell and mite }\end{array}$} & & \multirow{2}{*}{$\begin{array}{l}\text { Number } \\
\text { of } \\
\text { cells }\end{array}$} & \multicolumn{2}{|c|}{$\begin{array}{l}\text { Offspring per } \\
\text { cell and mite }\end{array}$} & \\
\hline & & female & male & & & female & male & \\
\hline 1 & 316 & 1.40 & 0.63 & 31 & 279 & 2.21 & 0.61 & 22 \\
\hline 2 & 158 & 1.09 & 0.65 & 37 & 249 & 1.90 & 0.59 & 24 \\
\hline 3 & 66 & 1.16 & 0.59 & 34 & 154 & 1.52 & 0.58 & 28 \\
\hline 4 & 30 & 0.91 & 0.58 & 39 & 84 & 1.51 & 0.51 & 25 \\
\hline 5 & 14 & 1.13 & 0.57 & 34 & 46 & 1.36 & 0.57 & 30 \\
\hline 6 & 3 & 0.93 & 0.17 & 15 & 38 & 1.35 & 0.55 & 29 \\
\hline 7 & 1 & 1.11 & 0.43 & 28 & 22 & 1.04 & 0.49 & 32 \\
\hline 8 & & & & & 10 & 1.18 & 0.67 & 36 \\
\hline 9 & & & & & 7 & 0.95 & 0.62 & 39 \\
\hline 10 & & & & & 7 & 0.86 & 0.44 & 34 \\
\hline 11 & & & & & 3 & 0.50 & 0.35 & 41 \\
\hline$\geq 12$ & & & & & 7 & 0.56 & 0.40 & 43 \\
\hline
\end{tabular}


Figure 1 gives the reproduction per Varroa for drone cells and worker cells during a reproductive cycle. It shows a clear decrease in the worker cells, and an even more marked decline in the drone cells. In worker cells, it drops from a value of 1.4 with one Varroa per cell to about 1 with 4 Varroa per cell, while in drone cells reproduction is 2.2 with one Varroa and about 1 with 8 Varroa. If values are weighted according to the numbers of cells sampled, a logarithmic regression of $\log y=-0.046 x+0.181, r=-0.801$ for worker cells and of $\log y=-0.045 x$ $+0.363, r=-0.964$ for drone cells gives a slightly better fit than a linear regression.

Impact on reproduction in brood combs and on population growth

If a brood comb is infested, some cells will contain more and some cells less than the average numbers of Varroa. In the model calculations, this leads to a lessening of

\section{FEMALE OFFSPRING}

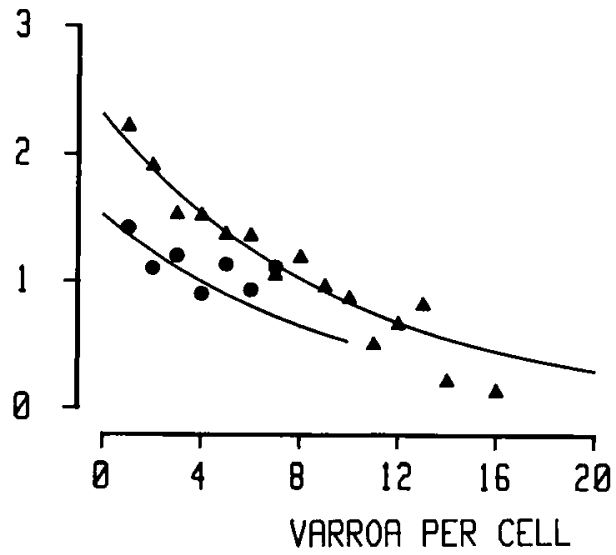

Fig. 1. Dependency of Varroa reproduction on the number of mites within one brood cell. Abscissa : numbers of Varroa infesting one brood cell; ordinate : mature female offspring per Varroa during one cell passage. = worker cells; $\boldsymbol{\Delta}=$ drone cells. the average reproduction for each of the calculated mean cell infestations (Fig. 2) as compared to reproduction in the single cells (values according to the above regressions). In the drone cells, this difference is most pronounced with one Varroa per cell and gets smaller with the higher values. In worker cells, the difference increases to the higher values as an effect of non-developing cells with more than 7 Varroa per cell.

In addition, if both types of cells are present at the same time and mites distribute according to an 8-fold drone cell preference, the mean cell infestations of both types will depend upon their proportions and on the mean brood cell infestation. The reproduction of both cell types together is shown for 50,10 and $5 \%$ drone cells, respectively.

Figure 3 shows how population growth could be affected by the densitydependent reproduction within combs (Fig. 2). Starting with a cell infestation rate of $1 / 10$ th, without effects of multiple

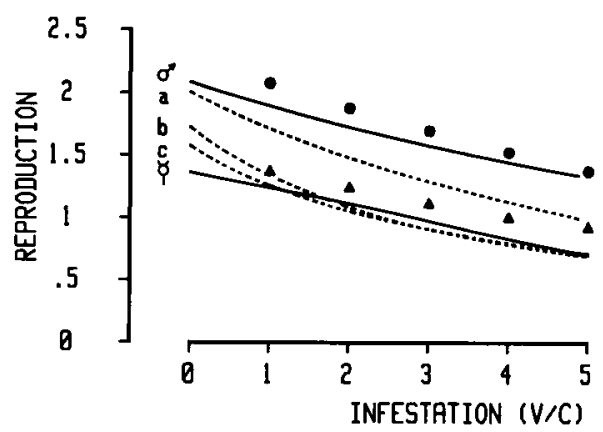

Fig. 2. Reproduction of Varroa within brood combs. Abscissa : infestation rate $\mathrm{V} / \mathrm{C}=$ Varroa per brood cell; ordinate : reproduction = female mature offspring per Varroa. Reproduction within single cells : $=$ = drone cells, $\boldsymbol{\Delta}=$ worker cells. Reproduction within brood combs : $\sigma^{\prime}=$ drone cells only, $\phi=$ worker cells only, $a=50 \%$ drone cells, $b=10 \%$ drone cells, $c=5 \%$ drone cells. 


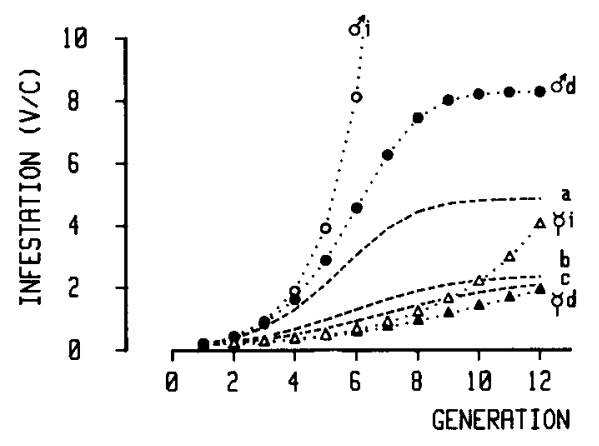

Fig. 3. Model calculation of Varroa population increase. Abscissa : number of generations; ordinate : population size in terms of cell infestation ( $V / C=$ Varroa per brood cell). Density-independent reproduction : $\sigma^{\prime} \mathrm{i}=$ drone; $\forall \mathbf{i}=$ worker combs. Density-dependent reproduction : $\sigma \mathbf{d}=$ drone; $\forall \mathbf{d}=$ worker combs. Mixed combs : $a=50 \%, b=10 \%$ and $c=5 \%$ drone cells.

infestation on reproduction, simple logarithmic growth curves result, with a considerable difference of 164 times as much Varroa being produced within drone cells as compared to worker cells after 12 generations. With density-dependent reproduction, population growth is slower and reaches an upper limit at 8 Varroa per cell in the drone combs. In worker combs, growth is only about half that of unrestricted growth after 12 generations, but does not reach a plateau within this period. With both drone and worker cells, population increase is, at first, accelerated if compared to the presence of worker brood alone. However, only with the very high proportion of $50 \%$ drone cells does this results in substantially more Varroa after 12 generations, whereas with 10 and $5 \%$ the difference is only slight.

\section{Discussion}

\section{Reproduction within cells}

In different studies on Varroa reproduction, the numbers of female offspring differ considerably (Schultz, $1984: 1.3$ in worker cells, 2.6 in drone cells; Ifantidis, $1984: 0.71$ in worker cells, 1.70 in drone cells). These differences may partially depend upon the methods, partially on reproductive differences between samples. Specifically, numbers of non-reproducing or abnormally reproducing Varroa vary considerably (Schultz : 27 and $5 \%$, respectively; Ifantidis : 19 and $5 \%$, respectively). As a result, reproduction is more consistent in respect to mites showing a 'normal' pattern (Schultz: 1.82 in worker cells and 2.69 in drone cells; Ifantidis : 1.33 and 2.77 , respectively; this study : 1.69 and 2.76). Thus, Varroa reproduction is highly dependent upon the proportions of subgroups with normal or deviate reproduction.

Reproduction per female mite is strongly influenced by the numbers of mites entering cells and is reduced by the addition of even one mite in both cell types. With numbers higher than 4 mites in worker cells or $\mathbf{8}$ mites in drone cells, reproduction per mite drops below 1 female offspring per reproductive cycle. This corresponds to a quite high infestation rate where colonies are already at risk of dying.

The lower net reproduction in multipleinfested brood cells could be produced by some of the mites suppressing reproduction in others, e.g., by commotion or other causes. This would mean that some mites do not reproduce at all, while others reproduce normally. Assuming the normal pattern of reproduction, where the 
first egg is female, the second male and all following female, the complete nonreproduction of some females should leave the offspring sex ratio unaffected but decrease the numbers of males produced per female if cells get more crowded.

As a second possibility, a lower number of offspring could be produced per female, e.g., from a depletion of resources or changing of the host' hemolymph composition. In this case, all Varroa should produce only the first few eggs. This would first reduce the later female eggs with the result of an increase in the proportion of males, until the male egg is also affected with a subsequent decrease of the male proportion. This interpretation is supported by the data in Table III. In drone cells, where several female eggs can develop after the male egg, the ratio of females to males drops until it comes close to 1:1. In worker cells, with rarely more than one female offspring after the male, the proportion of females first drops but then rises again.

\section{Reproduction within combs and population growth}

Within whole combs, the infestation of the single cells deviates from the mean infestation by a distribution, which can be closely approximated by superposition of several Poisson distributions (Fuchs, $1985 ; 1988)$. Usually this distribution has an extended tail towards cells with comparatively high numbers of mites. In these highly infested cells, reproduction per female is low. In addition, pupae in cells containing exceptionally high numbers of mites (worker cells : 7 , drone cells, 16) can be assumed to be killed. By these effects, the reproduction within whole combs could be demonstrated to be even lower than that within single cells containing the comb average of mites.
If drone cells are present at the same time as worker cells at reasonable proportions of $5-10 \%$, and mites enter drone cells with an 8-fold preference, the enhancement of reproduction, as compared to the reproduction in worker cells alone, declines rapidly as the mean cell infestation increases. With infestation rates of 2 Varroa per cell, it might even be lower. However, mean infestations in this range are already above that tolerated by a colony.

The dependency of reproduction on cell infestation rates constitutes an element of density-dependent population growth. The possible impact can be evaluated by computer calculations. In the present case, these are not intended to give true values of population growth. Real Varroa populations are affected by other factors. For an example, population growth is substantially dependent upon the number of cell passages of a mite, which is still being debated (lfantidis, 1984; DeRuijter, 1987). The present calculations are meant only to demonstrate the possible impact of increasing cell infestation on population growth.

The chosen period of 12 Varroa generations covers a period of approximately one brood season $(7-8$ months). In worker brood cells and starting with 0.1 Varroa per cell, the restricted reproduction gives approximately half the number of mites compared to unrestricted reproduction. This is a considerable difference, but it should be noted that, in both cases, infestation is within a range deleterious to the colony's survival. In drone cells alone, effects would be far more clear-cut, since after about 8 generations no more growth would be possible. Again, this is within a range of infestation unrealistically high in a natural situation. 
However, the calculations with both drone cells and worker cells show that with realistic proportions of drone cells of $10 \%$ or less, reproduction will be only slightly above that with worker brood cells alone after 12 generations. This indicates that small amounts of drone cells will get overcrowded if mite populations increase. As a consequence, they contribute far less to the population buildup than what would be expected from the higher reproductive potential of single mites in these cells.

\section{Sex ratio}

With increasing numbers of mites within a cell, the sex ratio moves towards (and within drone cells even approaches) equilibrium. This conforms to the predictions of the sex ratio theory (Fisher, 1930; Hamilton, 1967). With only one Varroa reproducing in the confinement of a brood cell, matings are between offspring without competition between males. Under these conditions, the production of only one male is most efficient, whereas, with increasing local competition, equal investments in both sexes pay. The restricted reproduction and the specific patterning of the production of female and male offspring thus results in an attunement of the sex ratio according to the degree of mate competition within the cells.

\section{Acknowlegments}

We thank M. Ullmann of the technical staff for providing materials, N. Koeniger and other collegues of the Institut für Bienenkunde for many discussions. The research was supported by DFG grant Ko $400 / 7-1$.

\section{References}

DeRuijter A. (1987) Reproduction of Varroa mites during successive brood cycles of the honeybee. Apidologie 18, 321-326

Fisher R.A. (1930) In : The Genetical Theory of Natural Selection. Clarendon Press, Oxford

Fuchs S. (1985) Untersuchungen zur quantitativen Abschätzung des Befalls von Bienenvölkern mit Varroa jacobsoni OUD. und zur Verteilung des Parasiten im Bienenvolk. Apidologie 16, 343-368

Fuchs S. (1988) The distribution of Varroa jacobsoni on honey bee brood combs and within brood cells as a consequence of fluctuating infestation rates. In : European research on varroatosis control (Cavalloro R., ed.) Proceedings of a meeting of the EC expert's group. Bad Hambourg, 15-17 October 1986, pp. 73-76

Hänel H. (1985) Das Juvenilhormon der Honigbiene als ein Auslöser für die Reproduktion des Parasiten Varroa jacobsoni Oud. unter Berücksichtigung der Morphologie des Reproduktions Systems der Milbe. Dissertation an der J.W. Goethe Universität Frankfurt/Main

Hamilton W.D. (1967) Extraordinary sex ratios. Science (N.Y.) 156, 477-488

Ifantidis M.D. (1983) Ontogenesis of the mite Varroa jacobsoni in worker and drone honeybee brood cells. J. Apic. Res. 22, 200206

Ifantidis M.D. (1984) Parameters of the population dynamics of the Varroa mite on honeybees. J. Apic. Res. 23, 227-233

Jay S.C. (1962) Color changes in honeybee pupae. Bee World 43, 119-122

Schulz A. (1984) Reproduktion und Populationsentwicklung der parasitischen Milbe Varroa jacobsoni Oud. in Abhängigkeit vom Brutzyklus ihres Wirts Apis mellifera L. Apidologie 15, 401420 